\title{
Cardiovascular Disease and Coronavirus Disease 2019: Epidemiology, Management, and Prevention
}

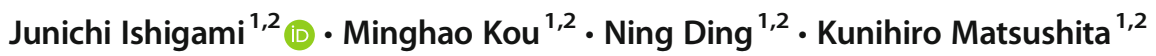 \\ Accepted: 17 December 2020 / Published online: 2 January 2021 \\ (C) The Author(s), under exclusive licence to Springer Nature Switzerland AG part of Springer Nature 2021
}

\begin{abstract}
Purpose of Review Coronavirus disease 2019 (COVID-19) has become a global pandemic associated with significant morbidity and mortality. This review summarizes findings up to date on the relationship between cardiovascular disease (CVD) and COVID-19.

Recent Findings Preexisting CVD is a common condition among patients with COVID-19 and is associated with increased disease severity and mortality. Conversely, COVID-19 has various clinical manifestations on cardiovascular system, including thrombotic events and cardiac dysfunction. The pandemic has impacted healthcare utilization among patients with CVD, which may have led to potential delay in access to the healthcare system during acute events not directly COVID-19-related.

Summary While COVID-19 vaccine is being developed and distributed, controlling CVD risk factors and adherence to recommendations of existing immunization (e.g., influenza vaccine) are key in protecting the health of individuals with CVD during the COVID-19 pandemic. Further research is needed to understand the epidemiological and pathophysiological basis for the interaction between CVD and COVID-19.
\end{abstract}

Keywords COVID-19 $\cdot$ Cardiovascular disease $\cdot$ Epidemiology $\cdot$ Risk factors $\cdot$ Management $\cdot$ Review

\section{Introduction}

Coronavirus disease 2019 (COVID-19) is a respiratory illness caused by severe acute respiratory syndrome coronavirus 2 (SARS-CoV-2). Since the first case report in December 2019, COVID-19 has rapidly grown to a global pandemic [1]. High contagiousness of SARS-CoV-2 is a major challenge to contain the disease spread $[2 \cdot, 3]$. The symptoms of COVID-19 are variable. The majority of patients have no symptom or mild respiratory symptoms [1]. However, some patients develop severe diseases including multi-organ failure and die due to COVID-19 [1]. Significant portions of

This article is part of the Topical Collection on Cardiovascular Disease

Junichi Ishigami

jishiga1@jhu.edu

1 Department of Epidemiology, Johns Hopkins Bloomberg School of Public Health, 2024 E. Monument St., Baltimore, MD 21287, USA

2 Welch Center for Prevention, Epidemiology, and Clinical Research, Johns Hopkins Bloomberg School of Public Health, Baltimore, MD, USA morbidity and mortality have occurred in individuals with risk factors, such as older age and underlying chronic diseases [1].

Cardiovascular disease (CVD) has been shown as a key underlying disease leading to severe manifestation of COVID-19 [4, 5•]. Also, cardiovascular complications of COVID-19 have been recognized. This review summarizes recent literature on the bidirectional relationship between CVD and COVID-19. We also discuss the impact of COVID-19 on healthcare utilization for patients with CVD and how individuals with CVD should protect themselves from COVID-19.

\section{The Prevalence of CVD Among COVID-19 Cases}

Studies have consistently shown CVD as a common underlying condition among COVID-19 patients, although the prevalence substantially varied across countries and regions. The United States (US) Center for Disease Control and Prevention has reported that CVD was prevalent in $9.0 \%$ of patients with COVID-19, which was similar to the prevalence of chronic lung disease (9.2\%) and diabetes (10.9\%) [6]. Across different reports, the prevalence of different CVD subtypes among COVID-19 patients ranged from 2.5 to $17.7 \%$ for coronary 
heart disease, 0.8 to $21.0 \%$ for heart failure, and 1.0 to $19.0 \%$ for atrial fibrillation $[7-12,13 \cdot 14,15,16 \cdot 17-20]$.

\section{CVD as a Potential Risk Factor of Severe COVID-19}

In a systematic review and meta-analysis pooling estimates from 10 studies with nearly 30,000 patients with COVID19 , patients with prior CVD had an approximately 5 times higher risk of severe COVID-19 (i.e., mortality, intensive care unit [ICU] admission, acute respiratory distress syndrome, or the need for mechanical ventilation) compared to those without prior CVD [5•]. Similar associations have been reported across different definitions of severe COVID-19 such as ICU admission [17, 18, 21], acute respiratory distress syndrome $[11,22]$, and all-cause mortality $[11,23,24]$.

We should recognize that most previous studies did not account for major confounders, such as hypertension and diabetes, when exploring prior CVD as a risk factor for severe COVID19. Nonetheless, a few studies have reported an independent association of CVD with severe COVID-19 (Table 1). Also, given prior CVD as a potent prognostic factor in general, it is intuitive that prior CVD is associated with poor prognosis in patients with COVID-19 as well. An unanswered question is whether persons with prior CVD are more susceptible to SARS-CoV-2 infection compared to those without CVD.
Potential Mechanisms Linking CVD to Severe COVID19

There are a few potential mechanisms that may explain the increased risk of severe COVID-19 in patients with prior CVD. First of all, as noted above, CVD is a potent prognostic factor regardless of COVID-19. Thus, risk factors of CVD such as older age, hypertension, and diabetes may also play a role in this regard [11,21]. Indeed, a number of studies have reported that these CVD risk factors are associated with severe manifestation of COVID-19 [4, 5•, 25, 26].

In addition, the interplay between the immune system and CVD is known, which may be relevant to the increased risk of severe COVID-19. Epidemiological studies have shown a prospective association between CVD and subsequent risk of different types of infection [27-29]. Also, immune cells are broadly recruited to the myocardial tissue in response to cardiac injury to remove dying tissue, scavenge pathogens, and promote healing [30]. However, these immune cell activities may disrupt the local or systemic host immune response, increasing susceptibility to viral myocarditis and sepsis [31]. Although data on COVID-19 are sparse, a small Chinese cross-sectional study of 64 patients with COVID-19 found that levels of inflammatory markers, such as high sensitivity C-reactive protein, interleukin-6, and tumor necrosis factor

Table 1 Representative studies assessing the independent association of CVD with severe COVID-19

\begin{tabular}{|c|c|c|c|c|}
\hline First author & Country & CVD subtype & $\begin{array}{l}\text { Severe COVID- } \\
19 \text { definition }\end{array}$ & Key findings \\
\hline $\begin{array}{l}\text { Cummings } \\
\text { MJ }\end{array}$ & USA & $\begin{array}{l}\text { Chronic cardiac disease (coronary artery } \\
\text { disease or congestive heart failure) }\end{array}$ & In-hospital death & $\begin{array}{l}\text { Among } 257 \text { critically ill patients, preexisting chronic cardiac } \\
\text { disease was associated with a higher risk of mortality (HR } \\
1.76[95 \% \mathrm{CI}, 1.08-2.86])^{*}\end{array}$ \\
\hline Bhatla A & USA & Atrial fibrillation & $\begin{array}{l}\text { Admission to the } \\
\text { ICU }\end{array}$ & $\begin{array}{l}\text { Among } 700 \text { hospitalized patients, incident atrial fibrillation } \\
\text { was associated with admission to the ICU (OR } 4.68 \\
[1.66-13.18]) \dagger\end{array}$ \\
\hline Shi S & China & $\begin{array}{l}\text { Cardiac injury (blood levels of cardiac } \\
\text { troponin I above the } 99 \text { th percentile } \\
\text { upper reference limit) }\end{array}$ & In-hospital death & $\begin{array}{l}\text { Among } 416 \text { hospitalized patients, cardiac injury was } \\
\text { associated with a higher risk of in-hospital death from } \\
\text { symptom onset (HR } 4.26[1.92-9.49])+\end{array}$ \\
\hline Song Y & China & $\begin{array}{l}\text { Cardiac injury (an elevated cardiac troponin } \\
\text { value above the 99th percentile of the } \\
\text { upper reference limit) }\end{array}$ & In-hospital death & $\begin{array}{l}\text { Among } 64 \text { critically ill patients, myocardial injury was an } \\
\text { independent risk factor for mortality (HR 2.06 [1.10-3.83] } \\
\S\end{array}$ \\
\hline Wang L & China & CVD & In-hospital death & $\begin{array}{l}\text { Among } 339 \text { patients, CVD was associated with in-hospital } \\
\text { death (HR } 2.06[1.10-3.83]) \text { I }\end{array}$ \\
\hline
\end{tabular}

*Adjusted for age, sex, symptom duration before hospital presentation, hypertension, chronic obstructive pulmonary disease, chronic kidney disease, diabetes, interleukin-6, D-dimer

$\dagger$ Adjusted for age, sex, race, body mass index, heart failure, coronary heart disease, diabetes, hypertension, chronic kidney disease, and hydroxychloroquine treatment

\$Adjusted for age, cardiovascular disease, cerebrovascular disease, diabetes, chronic obstructive pulmonary disease, renal failure, cancer, acute respiratory distress syndrome, creatinine $(\geq 1.50 \mathrm{mg} / \mathrm{d}$ or not) and $\mathrm{N}$-terminal pro-B-type natriuretic peptide ( $\geq 900 \mathrm{pg} / \mathrm{mL}$ or not)

$\S$ Adjusted for age, smoking history and preexisting with CVD

I[Adjusted for age, CVD, chronic obstructive pulmonary disease, and cerebrovascular disease

CVD cardiovascular disease, HR hazard ratio, ICU intensive care unit, OR odds ratio 
alpha, were higher among patients with myocardial injury than those without [32].

\section{The Impact of COVID-19 on the Cardiovascular System}

A number of studies have reported the impact of COVID-19 on the cardiovascular system. Its impact may vary from cardiac damage to thrombotic events. The bidirectional association between CVD and COVID-19 can create a vicious cycle and bring immense challenges in the care of patients with COVID19. In this section, we summarize a few representative cardiovascular manifestations in patients with COVID-19.

\section{Cardiac Damage}

A few studies reported abnormal echocardiographic findings in approximately 60 to $70 \%$ of hospitalized COVID-19 patients $[33 \bullet \cdot, 34]$. An international study including 1272 COVID-19 patients from 69 countries showed that 39\% of hospitalized COVID-19 patients had left ventricular abnormality (i.e., dilation, systolic dysfunction, and diastolic dysfunction), $33 \%$ had right ventricular abnormality, and $28 \%$ had biventricular failure [33••]. Furthermore, a case series autopsy study of patients with COVID-19 has shown that myocyte necrosis and mononuclear cell infiltrates were observed in cardiac muscle autopsy specimens [35]. Another case report has demonstrated that viral particles were found in cardiac tissues obtained from a patient with COVID-19 [36].

In addition to functional and structural abnormality of the heart, elevated levels of cardiac markers such as cardiac troponin $\mathrm{T}$ and I were observed in 7 to $36 \%$ of hospitalized patients with COVID-19 [7, 19, 20]. Higher levels of troponin were associated with a higher risk of ICU admission and mortality $[7,14,19,20]$. Of note, this association was observed regardless of a history of CVD [20]. Thus, cardiac markers may be utilized in stratifying the risk of adverse events among hospitalized patients with COVID-19. Such a risk classification may be especially useful when resources for clinical management are limited.

\section{Arrhythmias}

A variety of arrhythmia, including atrial fibrillations, ventricular tachycardias, and ventricular fibrillations, have been reported in patients with COVID-19 [17, 18, 20]. A study from the USA including 700 patients with COVID-19 found that 53 (8\%) patients developed arrhythmia-related events during hospitalization, including 9 cardiac arrests, 25 atrial fibrillations, 9 clinically significant bradyarrhythmias, and 10 nonsustained ventricular tachycardias [17]. These observations further support the potential pathophysiological impact of COVID-19 on the heart.

\section{Thrombotic Events}

COVID-19 may interfere with the coagulation system as well. The incidence of venous thrombosis and pulmonary embolism has been reported to be high in patients with COVID19 [37-40]. In a systematic review of 20 studies with 1988 patients with COVID-19, on average, venous thromboembolism events were recognized in $31.3 \%$ of the patients [37]. Other types of thrombotic events including the arterial system have also been reported in patients with COVID-19, such as myocardial infarction [41] and stroke [42-44]. Thrombotic events were consistently associated with a higher risk of mortality [38, 40, 41]. In addition, a few studies have reported elevated levels of D-dimer among patients with COVID-19 and their association with an increased risk of thrombotic events and mortality $[14,40]$. Accordingly, the International Society of Thrombosis and Hemostasis recommends using a prophylactic dose of low-molecular weight heparin for all hospitalized COVID-19 patients without contraindications [45].

\section{The Management of CVD in the Context of COVID-19}

\section{The Impact of COVID-19 on the Management of CVD}

A rapid surge in COVID-19 cases has strained healthcare systems and posed a great threat to the care for patients with CVD, especially in heavily hit areas such as the Hubei province in China, the state of New York in the USA, and the Lombardy region in Italy [46-48]. Several healthcare systems have observed a marked reduction (approximately 40\%) in the number of diagnoses and hospitalizations for acute CVD events during the COVID-19 pandemic such as acute coronary syndrome [49, 50], decompensated heart failure [51], and stroke [52].

These observations have raised concerns about delays in access to healthcare systems and the initiation of treatment among patients with new-onset CVD [53]. A study from Italy showed that patients with acute coronary syndrome during the COVID-19 outbreak had a substantially delayed time from symptom onset to hospital admission compared to preoutbreak (median of 15 hours versus 2 hours) [54]. Other studies have also shown a delay in treatment timelines and an increase in the rates of in-hospital mortality and out-ofhospital cardiac arrest $[47,55,56]$.

Accordingly, some countries have modified clinical guidelines for the management of CVD. For example, experts from China recommend thrombolytic treatment as the first-line therapy for patients with ST-elevated myocardial infarction when COVID-19 is confirmed or suspected [57]. This recommendation is likely to reflect local resources and settings (e.g., the number of catheterization labs equipped for the adequate protection of healthcare professionals) [58]. 


\section{Optimizing the Management of CVD and its Risk Factors}

As we discussed earlier, prior CVD has been associated with an increased risk of severe COVID-19 in a number of studies. Thus, CVD patients need to be among the top priorities for the prevention of COVID-19. Also, the value of controlling CVD risk factors should be emphasized during the outbreak of COVID19 , although the management of CVD risk factors may not be prioritized when the healthcare system is stretched due to the outbreak.

In the early stages of the COVID-19 pandemic, several researchers raised concerns about the use of angiotensinconverting enzyme inhibitors (ACEI) and angiotensin receptor blockers (ARB) for patients with COVID-19 [59, 60]. The concern was mainly driven by experimental data on ACEI and $\mathrm{ARB}$ as potentially increasing the relative abundance of ACE2 , a receptor used for SARS-CoV-2 for entering into the cell [61, 62]. However, subsequent studies have shown that the use of ACEI/ARB was not associated with an increased risk of COVID-19 infection, severity, or mortality [63-65]. To date, all major clinical guidelines state that ACEI and ARB should not be discontinued because of COVID-19 [66-69].

Most patients with CVD and its risk factors require continuous medical management. In this regard, telemedicine has been attracting attention as a way to interact with patients without direct person-to-person contact [70, 71•]. Previous studies have demonstrated that telemedicine was feasibly implemented in the care of conditions related to CVD risk factors, such as hypertension and diabetes [72, 73]. Indeed, the COVID-19 pandemic has resulted in a dramatic increase in the utilization of telemedicine. The US Department of Health and Human Services has reported that $44 \%$ of Medicare primary care visits were provided via telehealth in April 2020, as compared to merely $0.1 \%$ before the pandemic in February 2020 [74]. Nonetheless, several challenges remain to be solved before telemedicine can be widely adopted, such as technological barriers, the potential for such an approach to widen disparities, and potentially adverse effects on the patient-provider relationship $[75,76]$.

Smoking cessation is critically important since current/ former smoking was strongly associated with adverse outcomes of COVID-19 [5•]. Feelings of stress during the pandemic can drive an increase in the dose of smoking among current smokers [77, 78]; a survey has shown a dosedependent association between stress and smoking in a positive direction [79]. Other health behaviors may also be relevant, since some evidence suggests increases in alcohol consumption [80] and decreases in daily physical activity [81] during the COVID-19 pandemic.

\section{Optimizing Immunization in CVD Patients}

Adherence to existing immunization recommendations is critical to mitigate morbidities associated with COVID-19 [82].
Influenza and pneumococcal vaccines are particularly relevant since they can reduce the risk of respiratory infection and subsequent complications [83-86]. Coinfection is common in COVID-19, reported in up to $20 \%$ of COVID-19 patients on samples from nasopharyngeal swabs [87]. Although data are limited in COVID-19, studies among hospitalized patients with infection have shown that coinfection with virus or bacteria was associated with an increased risk of developing acute respiratory distress syndrome [88], requiring ICU admission [89], and mortality [90, 91]. Of note, the US Advisory Committee on Immunization Practices recommends influenza vaccination for all adults and pneumococcal vaccination for older adults and those with risk conditions including heart disease [92].

Efforts are underway to develop, test, and distribute vaccines against SARS-CoV-2. For equitable allocation of vaccines, the World Health Organization proposes that healthcare workers, older adults, and those with high-risk conditions including CVD should be prioritized for vaccination [93]. A recent study of 19,793 US adults with CVD demonstrated that sociodemographic factors, such as lack of a usual source of care or health insurance and having a low income and education level, were major barriers to influenza vaccination [94••]. Thus, public support would be needed for fair distribution of forthcoming vaccines against SARS-CoV-2. Skepticism on vaccine safety and efficacy in some individuals would be another important issue relevant for effective and efficient prevention of COVID-19 [95, 96].

\section{Potential Future Directions}

Despite an unprecedented surge in the number of publications related to COVID-19 since the beginning of the pandemic, our understanding of the relationship between CVD and COVID19 is still limited. Many observational studies did not account for major confounders of the association between CVD and COVID-19, and the magnitude of the association varied across countries and regions. Thus, further studies are needed to quantify the independent association of CVD with the risk of COVID-19. Also, rigorous evidence is needed to optimize the management of CVD and COVID-19. For example, cases of medication-induced arrhythmia, such as QT prolongation and sudden cardiac death, have been reported in patients with COVID-19 who received a compassionate drug use of hydroxychloroquine or azithromycin [97, 98].

To date, only short-term outcomes of COVID-19 are available. However, several studies have suggested the potential longer term impact of COVID-19, such as lingering symptoms following COVID-19 [99, 100] and reinfection of COVID-19 [101]. Thus, continued follow-up for patients with COVID-19 is needed to determine the long-term consequence of COVID-19 on the cardiovascular system. Finally, as COVID-19 will likely continue to pose challenges to our 
healthcare system (e.g., optimization of telemedicine, dissemination of COVID-19 vaccine), comprehensive approaches that involve policy- and system-level interventions are needed to ensure equal and equitable healthcare delivery for individuals with CVD and its risk factors in this new era.

\section{Conclusions}

A body of evidence suggests that there is a bidirectional relationship between CVD and COVID-19, which may present challenges in the prevention and management of patients with CVD and COVID-19 during the course of this pandemic. A rapid surge in COVID-19 cases has strained the healthcare system and has complicated the management of CVD and its risk factors. While we are awaiting the wide availability of COVID-19 vaccine, the management of CVD risk factors and adherence to immunization recommendations are critically important for individuals with CVD. Telemedicine may be a promising tool to provide CVD care while minimizing inperson clinic visits. Further research is needed to understand the epidemiological and pathophysiological basis for the interaction between CVD and COVID-19.

Funding Information All authors received support from the Resolve to Save Lives, which is funded by Bloomberg Philanthropies, the Bill and Melinda Gates Foundation, and Gates Philanthropy.

\section{Compliance with Ethical Standards}

Conflict of Interest Junichi Ishigami, Minghao Kou, and Ning Ding declare that they have no conflict of interest.

Kunihiro Matsushita reports grants from Resolve to Save Lives, during the conduct of the study.

Human and Animal Rights and Informed Consent This article does not contain any studies with human or animal subjects performed by any of the authors.

\section{References}

Papers of particular interest, published recently, have been highlighted as:

- Of importance

•. Of major importance

1. World Health Organization. Coronavirus disease (COVID-19) pandemic. Available: https:/www.who.int/emergencies/diseases/ novel-coronavirus-2019. Accessed September 19, 2020.

2. Lee S, Kim T, Lee E, Lee C, Kim H, Rhee H, et al. Clinical course and molecular viral shedding among asymptomatic and symptomatic patients with SARS-CoV-2 infection in a Community Treatment Center in the Republic of Korea. JAMA Intern Med. 2020. https://doi.org/10.1001/jamainternmed.2020.3862 This article reports the potential of disease transmission between asymptomatic patients. The findings highlight challenges of containing the spread of COVID-19.

3. Shen Y, Li C, Dong H, Wang Z, Martinez L, Sun Z, et al. Community outbreak investigation of SARS-CoV-2 transmission among bus riders in eastern China. JAMA Intern Med. 2020;180: 1665. https://doi.org/10.1001/jamainternmed.2020.5225.

4. Zheng Z, Peng F, Xu B, Zhao J, Liu H, Peng J, et al. Risk factors of critical \& mortal COVID-19 cases: a systematic literature review and meta-analysis. The Journal of infection. 2020;81(2): e16-25. https://doi.org/10.1016/j.jinf.2020.04.021.

5. Matsushita K, Ding N, Kou M, Hu X, Chen M, Gao Y, et al. The Relationship of COVID-19 severity with cardiovascular disease and its traditional risk factors: a systematic review and meta-analysis. Global Heart. 2020;15(1):64. https://doi.org/10.5334/gh.814 This is the first systemic review and meta-analysis focusing on the relationship of severe COVID-19 with CVD and its risk factors.

6. Team CC-R. Preliminary estimates of the prevalence of selected underlying health conditions among patients with coronavirus disease 2019 - United States, February 12-March 28, 2020. MMWR Morb Mortal Wkly Rep. 2020;69(13):382-6. https://doi.org/10. 15585/mmwr.mm6913e2.

7. Lala A, Johnson KW, Januzzi JL, Russak AJ, Paranjpe I, Richter $\mathrm{F}$, et al. Prevalence and impact of myocardial injury in patients hospitalized with COVID-19 infection. J Am Coll Cardiol. 2020;76(5):533-46. https://doi.org/10.1016/j.jacc.2020.06.007.

8. Iaccarino G, Grassi G, Borghi C, Ferri C, Salvetti M, Volpe M, et al. Age and multimorbidity predict death among COVID-19 patients: results of the SARS-RAS study of the Italian Society of Hypertension. Hypertension (Dallas, Tex : 1979). 2020;76(2): 366-72. https://doi.org/10.1161/HYPERTENSIONAHA.120. 15324.

9. Shi S, Qin M, Cai Y, Liu T, Shen B, Yang F, et al. Characteristics and clinical significance of myocardial injury in patients with severe coronavirus disease 2019. Eur Heart J. 2020;41(22):2070-9. https://doi.org/10.1093/eurheartj/ehaa408.

10. Gao C, Cai Y, Zhang K, Zhou L, Zhang Y, Zhang X, et al. Association of hypertension and antihypertensive treatment with COVID-19 mortality: a retrospective observational study. Eur Heart J. 2020;41(22):2058-66. https://doi.org/10.1093/eurheartj/ ehaa433.

11. Inciardi RM, Adamo M, Lupi L, Cani DS, Di Pasquale M, Tomasoni D, et al. Characteristics and outcomes of patients hospitalized for COVID-19 and cardiac disease in northern Italy. Eur Heart J. 2020;41(19):1821-9. https://doi.org/10.1093/eurheartj/ ehaa388.

12. Price-Haywood EG, Burton J, Fort D, Seoane L. Hospitalization and mortality among black patients and white patients with Covid19. N Engl J Med. 2020;382(26):2534-43. https://doi.org/10. 1056/NEJMsa2011686.

13. Richardson S, Hirsch JS, Narasimhan M, Crawford JM, McGinn T, Davidson KW, et al. Presenting characteristics, comorbidities, and outcomes among 5700 patients hospitalized with COVID-19 in the New York City Area. JAMA. 2020;323(20):2052-9. https:// doi.org/10.1001/jama.2020.6775 This is the study with the largest sample size, reporting characteristics, comorbidities, and outcomes of patients with COVID-19.

14. Zhou F, Yu T, Du R, Fan G, Liu Y, Liu Z, et al. Clinical course and risk factors for mortality of adult inpatients with COVID-19 in Wuhan, China: a retrospective cohort study. Lancet. 2020;395(10229):1054-62. https://doi.org/10.1016/S01406736(20)30566-3.

15. Ni W, Yang X, Liu J, Bao J, Li R, Xu Y, et al. Acute myocardial injury at Hospital admission is associated with all-cause mortality in COVID-19. J Am Coll Cardiol. 2020;76(1):124-5. https://doi. org/10.1016/j.jacc.2020.05.007. 
16. Guan WJ, Ni ZY, Hu Y, Liang WH, Ou CQ, He JX, et al. Clinical characteristics of Coronavirus Disease 2019 in China. N Engl J Med. 2020;382(18):1708-20. https://doi.org/10.1056/ NEJMoa2002032 This article is one of the first papers that summarize clinical characteristics of patients with COVID-19.

17. Bhatla A, Mayer MM, Adusumalli S, Hyman MC, Oh E, Tierney A, et al. COVID-19 and cardiac arrhythmias. Heart Rhythm. 2020;17(9):1439-44. https://doi.org/10.1016/j.hrthm.2020.06. 016.

18. Wang D, Hu B, Hu C, Zhu F, Liu X, Zhang J, et al. Clinical characteristics of 138 hospitalized patients with 2019 novel coronavirus-infected pneumonia in Wuhan. China JAMA. 2020;323(11):1061-9. https://doi.org/10.1001/jama.2020.1585.

19. Shi S, Qin M, Shen B, Cai Y, Liu T, Yang F, et al. Association of cardiac injury with mortality in hospitalized patients with COVID19 in Wuhan. China JAMA Cardiol. 2020;5(7):802-10. https:// doi.org/10.1001/jamacardio.2020.0950.

20. Guo T, Fan Y, Chen M, Wu X, Zhang L, He T, et al. Cardiovascular implications of fatal outcomes of patients with coronavirus disease 2019 (COVID-19). JAMA Cardiol. 2020;5(7):811-8. https://doi.org/10.1001/jamacardio.2020.1017.

21. He F, Quan Y, Lei M, Liu R, Qin S, Zeng J, et al. Clinical features and risk factors for ICU admission in COVID-19 patients with cardiovascular diseases. Aging Dis. 2020;11(4):763-9. https:// doi.org/10.14336/AD.2020.0622.

22. Wu C, Chen X, Cai Y, Xia J, Zhou X, Xu S, et al. Risk factors associated with acute respiratory distress syndrome and death in patients with coronavirus disease 2019 pneumonia in Wuhan. China JAMA Intern Med. 2020;180(7):934-43. https://doi.org/ 10.1001/jamainternmed.2020.0994.

23. Wang L, He W, Yu X, Hu D, Bao M, Liu H, et al. Coronavirus disease 2019 in elderly patients: characteristics and prognostic factors based on 4-week follow-up. The Journal of Infection. 2020;80(6):639-45. https://doi.org/10.1016/j.jinf.2020.03.019.

24. Cummings MJ, Baldwin MR, Abrams D, Jacobson SD, Meyer BJ, Balough EM, et al. Epidemiology, clinical course, and outcomes of critically ill adults with COVID-19 in New York City: a prospective cohort study. Lancet. 2020;395(10239):1763-70. https://doi.org/10.1016/S0140-6736(20)31189-2.

25. Zhang J, Wu J, Sun X, Xue H, Shao J, Cai W, et al. Association of hypertension with the severity and fatality of SARS-CoV-2 infection: a meta-analysis. Epidemiol Infect. 2020;148:e106. https:// doi.org/10.1017/S095026882000117X.

26. Huang I, Lim MA, Pranata R. Diabetes mellitus is associated with increased mortality and severity of disease in COVID-19 pneumonia - a systematic review, meta-analysis, and meta-regression. Diabetes Metab Syndr. 2020;14(4):395-403. https://doi.org/10. 1016/j.dsx.2020.04.018.

27. van Hoek AJ, Andrews N, Waight PA, Stowe J, Gates P, George $\mathrm{R}$, et al. The effect of underlying clinical conditions on the risk of developing invasive pneumococcal disease in England. The Journal of infection. 2012;65(1):17-24. https://doi.org/10.1016/j. jinf.2012.02.017.

28. Almirall J, Bolibar I, Serra-Prat M, Roig J, Hospital I, Carandell E, et al. New evidence of risk factors for community-acquired pneumonia: a population-based study. Eur Respir J. 2008;31(6):127484. https://doi.org/10.1183/09031936.00095807.

29. Mor A, Thomsen RW, Ulrichsen SP, Sorensen HT. Chronic heart failure and risk of hospitalization with pneumonia: a populationbased study. European Journal of Internal Medicine. 2013;24(4): 349-53. https://doi.org/10.1016/j.ejim.2013.02.013.

30. Swirski FK, Nahrendorf M. Cardioimmunology: the immune system in cardiac homeostasis and disease. Nat Rev Immunol. 2018;18(12):733-44. https://doi.org/10.1038/s41577-018-00658.
31. Mann DL. The emerging role of innate immunity in the heart and vascular system: for whom the cell tolls. Circ Res. 2011;108(9): 1133-45. https://doi.org/10.1161/CIRCRESAHA.110.226936.

32. Song Y, Gao P, Ran T, Qian H, Guo F, Chang L, et al. High inflammatory burden: a potential cause of myocardial injury in critically ill patients with COVID-19. Front Cardiovasc Med. 2020;7(128):128. https://doi.org/10.3389/fcvm.2020.00128.

33.• Dweck MR, Bularga A, Hahn RT, Bing R, Lee KK, Chapman AR, et al. Global evaluation of echocardiography in patients with COVID-19. Eur Heart J Cardiovasc Imaging. 2020;21(9):949-58. https://doi.org/10.1093/ehjci/jeaa178 This article revealed a high prevalence of cardiac abnormalities among patients with COVID-19. Similar prevalenc of abnormalities between left and right ventricles suggest the broad impact of COVID19 on the heart.

34. Szekely Y, Lichter Y, Taieb P, Banai A, Hochstadt A, Merdler I, et al. Spectrum of cardiac manifestations in COVID-19: a systematic echocardiographic study. Circulation. 2020;142(4):342-53. https://doi.org/10.1161/CIRCULATIONAHA.120.047971.

35. Tavazzi G, Pellegrini C, Maurelli M, Belliato M, Sciutti F, Bottazzi A, et al. Myocardial localization of coronavirus in COVID-19 cardiogenic shock. Eur J Heart Fail. 2020;22(5): 911-5. https://doi.org/10.1002/ejhf.1828.

36. Lindner D, Fitzek A, Brauninger H, Aleshcheva G, Edler C, Meissner K, et al. Association of Cardiac Infection with SARSCoV-2 in confirmed COVID-19 autopsy cases. JAMA Cardiol. 2020;5:1281-5. https://doi.org/10.1001/jamacardio.2020.3551.

37. Di Minno A, Ambrosino P, Calcaterra I, Di Minno MND. COVID-19 and venous thromboembolism: a meta-analysis of literature studies. Semin Thromb Hemost. 2020;46:763-71. https:// doi.org/10.1055/s-0040-1715456.

38. Klok FA, Kruip M, van der Meer NJM, Arbous MS, Gommers D, Kant KM, et al. Confirmation of the high cumulative incidence of thrombotic complications in critically ill ICU patients with COVID-19: an updated analysis. Thromb Res. 2020;191:148 50. https://doi.org/10.1016/j.thromres.2020.04.041.

39. Wichmann D, Sperhake JP, Lutgehetmann M, Steurer S, Edler C, Heinemann A, et al. Autopsy findings and venous thromboembolism in patients with COVID-19: a prospective cohort study. Ann Intern Med. 2020;173(4):268-77. https://doi.org/10.7326/M202003.

40. Bilaloglu S, Aphinyanaphongs Y, Jones S, Iturrate E, Hochman J, Berger JS. Thrombosis in hospitalized patients with COVID-19 in a New York City health system. JAMA. 2020;324(8):799-801. https://doi.org/10.1001/jama.2020.13372.

41. Middeldorp S, Coppens M, van Haaps TF, Foppen M, Vlaar AP, Muller MCA, et al. Incidence of venous thromboembolism in hospitalized patients with COVID-19. J Thromb Haemost. 2020;18(8):1995-2002. https://doi.org/10.1111/jth.14888.

42. Mao L, Jin H, Wang M, Hu Y, Chen S, He Q, et al. Neurologic manifestations of hospitalized patients with coronavirus disease 2019 in Wuhan. China JAMA Neurol. 2020;77(6):683-90. https://doi.org/10.1001/jamaneurol.2020.1127.

43. Belani P, Schefflein J, Kihira S, Rigney B, Delman BN, Mahmoudi K, et al. COVID-19 is an independent risk factor for acute ischemic stroke. AJNR Am J Neuroradiol. 2020;41(8): 1361-4. https://doi.org/10.3174/ajnr.A6650.

44. Shahjouei S, Naderi S, Li J, Khan A, Chaudhary D, Farahmand G, et al. Risk of stroke in hospitalized SARS-CoV-2 infected patients: a multinational study. EBioMedicine. 2020;59:102939. https:// doi.org/10.1016/j.ebiom.2020.102939.

45. Thachil J, Tang N, Gando S, Falanga A, Cattaneo M, Levi M, et al. ISTH interim guidance on recognition and management of coagulopathy in COVID-19. J Thromb Haemost. 2020;18(5): 1023-6. https://doi.org/10.1111/jth.14810. 
46. New York City's Resuscitation Debate: COVID and Cardiac Arrest. https://www.emsworld.com/article/1224268/new-yorkcitys-resuscitation-debate-covid-and-cardiac-arrest (2020). Accessed Sep 152020.

47. Xiang D, Xiang X, Zhang W, Yi S, Zhang J, Gu X, et al. Management and outcomes of patients with STEMI during the COVID-19 pandemic in China. J Am Coll Cardiol. 2020;76(11):1318-24. https://doi.org/10.1016/j.jacc.2020.06. 039.

48. Rosenbaum L. Facing Covid-19 in Italy - ethics, logistics, and therapeutics on the Epidemic's front line. N Engl J Med. 2020;382(20):1873-5. https://doi.org/10.1056/NEJMp2005492.

49. Solomon MD, McNulty EJ, Rana JS, Leong TK, Lee C, Sung SH, et al. The Covid-19 pandemic and the incidence of acute myocardial infarction. N Engl J Med. 2020;383(7):691-3. https://doi.org/ 10.1056/NEJMc2015630.

50. Garcia S, Albaghdadi MS, Meraj PM, Schmidt C, Garberich R, Jaffer FA, et al. Reduction in ST-segment elevation cardiac catheterization laboratory activations in the United States during COVID-19 pandemic. J Am Coll Cardiol. 2020;75(22):2871-2. https://doi.org/10.1016/j.jacc.2020.04.011.

51. Andersson C, Gerds T, Fosbol E, Phelps M, Andersen J, Lamberts $\mathrm{M}$, et al. Incidence of new-onset and worsening heart failure before and after the COVID-19 epidemic lockdown in Denmark: a nationwide cohort study. Circ Heart Fail. 2020;13(6):e007274. https://doi.org/10.1161/CIRCHEARTFAILURE.120.007274.

52. Bhatt AS, Moscone A, McElrath EE, Varshney AS, Claggett BL, Bhatt DL, et al. Fewer hospitalizations for acute cardiovascular conditions during the COVID-19 pandemic. J Am Coll Cardiol. 2020;76(3):280-8. https://doi.org/10.1016/j.jacc.2020.05.038.

53. Roffi M, Guagliumi G, Ibanez B. The obstacle course of reperfusion for ST-segment-elevation myocardial infarction in the COVID-19 pandemic. Circulation. 2020;141(24):1951-3. https://doi.org/10.1161/CIRCULATIONAHA.120.047523.

54. Gramegna M, Baldetti L, Beneduce A, Pannone L, Falasconi G, Calvo F, et al. ST-segment-elevation myocardial infarction during COVID-19 pandemic: insights from a regional public service healthcare hub. Circ Cardiovasc Interv. 2020;13(8):e009413. https://doi.org/10.1161/CIRCINTERVENTIONS.120.009413.

55. Marijon E, Karam N, Jost D, Perrot D, Frattini B, Derkenne C, et al. Out-of-hospital cardiac arrest during the COVID-19 pandemic in Paris, France: a population-based, observational study. Lancet Public Health. 2020;5(8):e437-e43. https://doi.org/10. 1016/S2468-2667(20)30117-1.

56. Baldi E, Sechi GM, Mare C, Canevari F, Brancaglione A, Primi R, et al. Out-of-Hospital cardiac arrest during the Covid-19 outbreak in Italy. N Engl J Med. 2020;383(5):496-8. https://doi.org/10. 1056/NEJMc2010418.

57. Bu J, Chen M, Cheng X, Dong Y, Fang W, Ge J, et al. [Consensus of Chinese experts on diagnosis and treatment processes of acute myocardial infarction in the context of prevention and control of COVID-19 (first edition). Nan Fang Yi Ke Da Xue Xue Bao. 2020;40(2):147-51. https://doi.org/10.12122/j.issn.1673-4254. 2020.02.01

58. Jing ZC, Zhu HD, Yan XW, Chai WZ, Zhang S. Recommendations from the Peking union medical college Hospital for the management of acute myocardial infarction during the COVID-19 outbreak. Eur Heart J. 2020;41(19):1791-4. https://doi.org/10.1093/eurheartj/ehaa258.

59. Esler M, Esler D. Can angiotensin receptor-blocking drugs perhaps be harmful in the COVID-19 pandemic? J Hypertens. 2020;38(5):781-2. https://doi.org/10.1097/HJH. 0000000000002450 .

60. Fang L, Karakiulakis G, Roth M. Are patients with hypertension and diabetes mellitus at increased risk for COVID-19 infection?
Lancet Respir Med. 2020;8(4):e21. https://doi.org/10.1016/ S2213-2600(20)30116-8

61. Kuba K, Imai Y, Rao S, Gao H, Guo F, Guan B, et al. A crucial role of angiotensin converting enzyme 2 (ACE2) in SARS coronavirus-induced lung injury. Nat Med. 2005;11(8):875-9. https://doi.org/10.1038/nm1267.

62. Li F, Li W, Farzan M, Harrison SC. Structure of SARS coronavirus spike receptor-binding domain complexed with receptor. Science. 2005;309(5742):1864-8. https://doi.org/10.1126/ science. 1116480.

63. Pranata R, Permana H, Huang I, Lim MA, Soetedjo NNM, Supriyadi R, et al. The use of renin angiotensin system inhibitor on mortality in patients with coronavirus disease 2019 (COVID19): a systematic review and meta-analysis. Diabetes Metab Syndr. 2020;14(5):983-90. https://doi.org/10.1016/j.dsx.2020. 06.047.

64. Zhang X, Yu J, Pan LY, Jiang HY. ACEI/ARB use and risk of infection or severity or mortality of COVID-19: a systematic review and meta-analysis. Pharmacol Res. 2020;158:104927. https://doi.org/10.1016/j.phrs.2020.104927.

65. Fosbol EL, Butt JH, Ostergaard L, Andersson C, Selmer C, Kragholm K, et al. Association of angiotensin-converting enzyme inhibitor or angiotensin receptor blocker use with COVID-19 diagnosis and mortality. JAMA. 2020;324(2):168-77. https://doi. org/10.1001/jama.2020.11301.

66. COVID-19 and concerns regarding use of ACEi/ARB/ARNi medications for heart failure or hypertension. https://www.ccs. ca/images/Images_2020/CCS_CHFS_statement_regarding COVID_EN.pdf (2020). Accessed Sep 152020.

67. A statement from the International Society of Hypertension on COVID-19. https://ish-world.com/news/a/A-statement-from-theInternational-Society-of-Hypertension-on-COVID-19/ (2020). Accessed Sep 152020.

68. Position Statement of the ESC Council on Hypertension on ACEInhibitors and Angiotensin Receptor Blockers. https://www. escardio.org/Councils/Council-on-Hypertension-(CHT)/News/ position-statement-of-the-esc-council-on-hypertension-on-aceinhibitors-and-ang (2020). Accessed Sep 152020.

69. Bozkurt B, Kovacs R, Harrington B. Joint HFSA/ACC/AHA statement addresses concerns re: using RAAS antagonists in COVID-19. J Card Fail. 2020;26(5):370. https://doi.org/10.1016/ j.cardfail.2020.04.013.

70. Omboni S, McManus RJ, Bosworth HB, Chappell LC, Green $\mathrm{BB}$, Kario K, et al. Evidence and recommendations on the use of telemedicine for the management of arterial hypertension: an international expert position paper. Hypertension (Dallas, Tex : 1979). 2020;76(5):1368-83. https://doi.org/10.1161/ HYPERTENSIONAHA.120.15873.

71. hoffer-hawlik m, moran a, burka d, kaur $\mathrm{p}$, cai $\mathrm{j}$, frieden $\mathrm{t}$, et al. leveraging telemedicine for chronic disease management in lowand middle-income countries during Covid-19. Global Heart. 2020;15(1):63. https://doi.org/10.5334/gh.852 This article summarizes a potential of utiliizng telemedicine in the era of COVID-19.

72. Agarwal R, Bills JE, Hecht TJ, Light RP. Role of home blood pressure monitoring in overcoming therapeutic inertia and improving hypertension control: a systematic review and meta-analysis. Hypertension (Dallas, Tex : 1979). 2011;57(1):29-38. https://doi.org/10.1161/HYPERTENSIONAHA.110.160911.

73. Zullig LL, Melnyk SD, Goldstein K, Shaw RJ, Bosworth HB. The role of home blood pressure telemonitoring in managing hypertensive populations. Curr Hypertens Rep. 2013;15(4):346-55. https://doi.org/10.1007/s11906-013-0351-6.

74. Bosworth A RJ, Samson LW, Sheingold S, Taplin C, Tarazi W, and Zuckerman R, . Medicare beneficiary use of telehealthvisits: early data from the start of COVID-19 pandemic. Washington, 
DC: Office of the Assistant Secretary for Planning and Evaluation, U.S. Department of Health and Human Services. July 28, 2020.

75. Eberly LA, Khatana SAM, Nathan AS, Snider C, Julien HM, Deleener ME, et al. Telemedicine outpatient cardiovascular care during the COVID-19 pandemic: bridging or opening the digital divide? Circulation. 2020;142:510-2. https://doi.org/10.1161/ CIRCULATIONAHA.120.048185.

76. Scott Kruse C, Karem P, Shifflett K, Vegi L, Ravi K, Brooks M. Evaluating barriers to adopting telemedicine worldwide: a systematic review. J Telemed Telecare. 2018;24(1):4-12. https://doi.org/ $10.1177 / 1357633 X 16674087$.

77. Klemperer EM, West JC, Peasley-Miklus C, Villanti AC. Change in tobacco and electronic cigarette use and motivation to quit in response to COVID-19. Nicotine Tob Res. 2020;22(9):1662-3. https://doi.org/10.1093/ntr/ntaa072.

78. Yach D. Tobacco use patterns in five countries during the COVID-19 lockdown. Nicotine Tob Res. 2020;22(9):1671-2. https://doi.org/10.1093/ntr/ntaa097.

79. Bommele J, Hopman P, Walters BH, Geboers C, Croes E, Fong GT, et al. The double-edged relationship between COVID-19 stress and smoking: Implications for smoking cessation. Tob Induc Dis. 2020;18:63. https://doi.org/10.18332/tid/125580.

80. Pollard MS, Tucker JS, Green HD Jr. Changes in adult alcohol use and consequences during the COVID-19 pandemic in the US. JAMA Netw Open. 2020;3(9):e2022942. https://doi.org/10. 1001/jamanetworkopen.2020.22942.

81. Chen P, Mao L, Nassis GP, Harmer P, Ainsworth BE, Li F. Coronavirus disease (COVID-19): the need to maintain regular physical activity while taking precautions. J Sport Health Sci. 2020;9(2):103-4. https://doi.org/10.1016/j.jshs.2020.02.001.

82. Solomon DA, Sherman AC, Kanjilal S. Influenza in the COVID19 era. JAMA. 2020;324:1342-3. https://doi.org/10.1001/jama. 2020.14661.

83. Ishigami J, Padula WV, Grams ME, Chang AR, Jaar B, Gansevoort RT, et al. Cost-effectiveness of pneumococcal vaccination among patients with CKD in the United States. Am J Kidney Dis. 2019;74(1):23-35. https://doi.org/10.1053/j.ajkd. 2019.01.025.

84. Osterholm MT, Kelley NS, Sommer A, Belongia EA. Efficacy and effectiveness of influenza vaccines: a systematic review and meta-analysis. Lancet Infect Dis. 2012;12(1):36-44. https://doi. org/10.1016/S1473-3099(11)70295-X.

85. Nichol KL, Nordin JD, Nelson DB, Mullooly JP, Hak E. Effectiveness of influenza vaccine in the community-dwelling elderly. N Engl J Med. 2007;357(14):1373-81. https://doi.org/ 10.1056/NEJMoa070844.

86. Ishigami J, Sang Y, Grams ME, Coresh J, Chang A, Matsushita K. Effectiveness of influenza vaccination among older adults across kidney function: pooled analysis of 2005-2006 through 20142015 influenza seasons. Am J Kidney Dis. 2020;75(6):887-96. https://doi.org/10.1053/j.ajkd.2019.09.008.

87. Kim D, Quinn J, Pinsky B, Shah NH, Brown I. Rates of coinfection between SARS-CoV-2 and other respiratory pathogens. JAMA. 2020;323(20):2085-6. https://doi.org/10.1001/jama. 2020.6266.

88. Cilloniz C, Ewig S, Ferrer M, Polverino E, Gabarrus A, Puig de la Bellacasa J, et al. Community-acquired polymicrobial pneumonia in the intensive care unit: aetiology and prognosis. Crit Care. 2011;15(5):R209. https://doi.org/10.1186/cc10444.

89. Abelenda-Alonso G, Rombauts A, Gudiol C, Meije Y, Ortega L, Clemente $\mathrm{M}$, et al. Influenza and bacterial coinfection in adults with community-acquired pneumonia admitted to conventional wards: risk factors, clinical features, and outcomes. Open Forum Infect Dis. 2020;7(3):ofaa066. https://doi.org/10.1093/ofid/ ofaa066.

90. Martin-Loeches I, M JS, Vincent JL, Alvarez-Lerma F, Bos LD, sole-Violan J, et al. increased incidence of co-infection in critically ill patients with influenza. Intensive Care Med 2017;43(1):48-58. https://doi.org/10.1007/s00134-016-4578-y.

91. Crotty MP, Meyers S, Hampton N, Bledsoe S, Ritchie DJ, Buller RS, et al. Epidemiology, co-infections, and outcomes of viral pneumonia in adults: an observational cohort study. Medicine (Baltimore). 2015;94(50):e2332. https://doi.org/10.1097/MD. 0000000000002332.

92. Kim DK, Hunter P. Advisory committee on immunization practices recommended immunization schedule for adults aged 19 years or older - United States, 2019. MMWR Morb Mortal Wkly Rep. 2019;68(5):115-8. https://doi.org/10.15585/mmwr. mm6805a5.

93. World Health Organization. WHO SAGE values framework for the allocation and prioritization of COVID-19 vaccination. Available: https://www.who.int/immunization/policy/sage/en/. Accessed September 19, 2020.

94.• Grandhi GR, Mszar R, Vahidy F, Valero-Elizondo J, Blankstein $\mathrm{R}$, Blaha MJ, et al. Sociodemographic disparities in influenza vaccination among adults with atherosclerotic cardiovascular disease in the United States. JAMA Cardiol. 2020. https://doi.org/10. 1001/jamacardio.2020.3978 This article highlights significant sociodemographic disparities in the utilization of influenza vaccination in the US.

95. Fisher KA, Bloomstone SJ, Walder J, Crawford S, Fouayzi H, Mazor KM. Attitudes toward a potential SARS-CoV-2 vaccine: a survey of U.S. adults. Ann Intern Med. 2020. https://doi.org/10. 7326/M20-3569.

96. Neumann-Bohme S, Varghese NE, Sabat I, Barros PP, Brouwer $\mathrm{W}$, van Exel J, et al. Once we have it, will we use it? A European survey on willingness to be vaccinated against COVID-19. Eur J Health Econ. 2020;21(7):977-82. https://doi.org/10.1007/s10198020-01208-6.

97. Rosenberg ES, Dufort EM, Udo T, Wilberschied LA, Kumar J, Tesoriero J, et al. Association of treatment with hydroxychloroquine or azithromycin with in-hospital mortality in patients with COVID19 in New York state. JAMA. 2020;323(24):2493-502. https://doi. org/10.1001/jama.2020.8630.

98. Chorin E, Wadhwani L, Magnani S, Dai M, Shulman E, NadeauRouthier C, et al. QT interval prolongation and torsade de pointes in patients with COVID-19 treated with hydroxychloroquine/ azithromycin. Heart Rhythm. 2020;17(9):1425-33. https://doi. org/10.1016/j.hrthm.2020.05.014.

99. Mitrani RD, Dabas N, Goldberger JJ. COVID-19 cardiac injury: implications for long-term surveillance and outcomes in survivors. Heart Rhythm. 2020;17:1984-90. https://doi.org/10.1016/j.hrthm. 2020.06.026.

100. Fraser E. Long term respiratory complications of covid-19. BMJ. 2020;370:m3001. https://doi.org/10.1136/bmj.m3001.

101. Tillett RL, Sevinsky JR, Hartley PD, Kerwin H, Crawford N, Gorzalski A, et al. Genomic evidence for reinfection with SARS-CoV-2: a case study. Lancet Infect Dis. 2020. https://doi. org/10.1016/S1473-3099(20)30764-7.

Publisher's Note Springer Nature remains neutral with regard to jurisdictional claims in published maps and institutional affiliations. 